\title{
CHANGES IN MIGRATION TO RURAL REGIONS IN THE CZECH REPUBLIC: POSITION AND PERSPECTIVES
}

\author{
Marie NOVOTNÁ, Jiří PREIS, Jan KOPP, Michael BARTOŠ
}

\begin{abstract}
Migration trends in the Czech Republic after 1990 are discussed in this paper. To evaluate the migration trends, the databases of immigrants and emigrants from the Czech Statistical Office from 1990 to 2010, are used. While migration from rural areas to urban areas prevailed in the past, after 1990 the direction changed: the population in rural areas with good natural and socio-cultural environments has been increasing due to migration. Small municipalities have a positive migration balance. We can conclude that these trends could be influenced primarily by social and environmental problems in cities, the increase in automobile use and the development of communication technologies, the migration of pensioners who settle in second homes, and the changing residential preferences of people and entrepreneurs.
\end{abstract}

\section{Shrnutí}

\section{Migrační změny v rurálních regionech České republiky: stav a perspektivy}

Článek hodnotí migrační trendy ve venkovských oblastech v České republice po roce 1990. K hodnocení byla použita databáze přistěhovalých a vystěhovalých Českého statistického úradu za období 1990-2010. Zatímco v minulosti převažovala migrace $z$ venkovských oblastí do měst, po roce 1990 se směr migrace změnil: počet obyvatel ve venkovských oblastech s dobrým prírodním a přiznivým socio-kulturním prostředím roste díky migraci. Malé obce mají kladné migrační saldo. Lze predpokládat, že tyto trendy by mohly být ovliuněny predevším sociálními a ekologickými problémy ve městech, zvýšením motorizace a rozšírením komunikačních technologií, stěhováním důchodců do objektü druhého bydlení a změnami preferencí bydlení.

Keywords: counterurbanization, migration, rural areas, Šumava area, Třeboň area, West Inner Periphery, Czech Republic

\section{Introduction}

Rural areas constitute $73-82 \%$ of the Czech Republic land area (depending on specified criteria) and about $26-29 \%$ of the total population live in these regions. Their position and challenges are primarily evaluated and classified based on comparison with the main economic hubs (Hanousek et al., 2007). Common characteristics of such areas are lower levels of economic activity and depopulation. The potential for development can be the quality of the environment and that could bring many benefits. If these regions keep and protect their environment, they could encourage people living in large centres and other urban areas to move and to live there on a long-term basis. Our research project is focused on people migrating to rural areas due to the attraction of a better quality environment (both natural and social). This kind of population mobility

is called "amenity migration", common in the AngloSaxon literature (Moss, 1994; Glorioso, 1999). The goal of amenity migrants is to attain a better quality of life by living in places with higher quality of natural, social or cultural environments.

This paper evaluates the following issues:

- if migration trends in the Czech Republic have changed since the year 2000; whether migration streams have altered; and whether people do migrate into rural areas;

- then we analyse migration streams and trends in detail in three case study areas with high quality environments. These case studies are the Sumava area, including the foothills (A), the Třeboňsko area (B), and the "West Inner Periphery" area (C), which is demarcated along the border of 
the Plzeňský region, Ústecký region and the Středočeský region. We propose that these areas are drawing amenity migrants, given their natural and cultural potential.

This article is a revised and expanded version of the chapter: "Migration trends of inhabitants in rural space", which was published in the book "Amenitní migrace do venkovských oblastí České republiky" (Amenity Migration to Rural Areas in the Czech Republic - Bartoš et al., 2011).

\section{Theoretical background}

Migration is the most significant component in the spatial movement of populations. It dramatically influences population numbers and brings about changes in demographic, economic and social structures. There are predominantly negative impacts of those processes in the out-migration areas. The reduction of anthropogenic loading in an area left by emigrants, however, could have positive results. Conversely, in the in-migration areas, new people can become a fuel for future development, but also for anthropogenic loading on the territory.

Urbanization phases are defined in line with the theory of stages of urban development, according to the combined growth and decline of the urban centre and the urban fringe area (Ouředníček, 2000; Antrop, 2004). The theory of differential urbanization (Geyer and Kontuly, 1993) explains phases of urbanization as a diffusion wave. Antrop (2004) presents models of changing patterns of rural villages in Europe due to growth processes in the countryside. "Counterurbanization" is characterized as the third stage of urban development. The concept of "counterurbanization" is described by Mitchell (2004) as a migratory movement from "large" to "small" areas, as a negative relationship between settlement size and migration or as a negative relationship between settlement size and population growth.

Until the 1970s migration from rural areas to urban areas increased, but then this started to change. Boyle, Halfacree (1998) described the migration tendencies of the 1970s using the term "counterurbanization", a process in which people move from urban areas back to rural areas. Berry (1976) described this change in migration trends as well. Fielding (1992) carried out a deep analysis to verify these previously-mentioned changes and demonstrated the higher migration rates of people living in urban zones into rural settlements in the UK. This trend, however, has not been identified in all European countries, as indicated by Kontuly (1998). According to Walmsley (1998), counterurbanization in Australia (New South Wales) is long-standing as well. Migration processes from urban areas to the countryside in post-socialist countries have been discussed, especially with a focus on the phases of residential systems development according to the theory of differential urbanization (Kontuly and Geyer, 2003; Tammaru, 2003; Ouředníček, 2007; Šimon, 2011). Similar to the Czech Republic, migration from cities to rural areas was strengthened in Estonia in 1990s (Tammaru, 2003). However, it is not possible to unambiguously classify it in the model of differential urbanization (Kontuly, Geyer, 2003).

Suburbanization as a decentralizing migration process from urban areas generally prevails. It is not the only process, because residential deconcentration heads out of metropolitan areas too, especially to areas with predominantly rural traits (Šimon, Ouředníček, Novák, 2009). Berry (1976) calls both deconcentration processes, using the term "counterurbanization". It is not possible to consider "counterurbanization" as an opposite of the urbanization process, but rather as one of the follow-up processes (Šimon, 2011). An opposite term for urbanization could be considered "de-urbanization". Egan and Luloff (2000) use the term "exurbanization" for the process of urban people migrating to rural areas.

If we accept the concept of "counterurbanization" as a part of the urbanization process (Champion, 2001), then according to Čermák et al. (2009), both counterurbanization and suburbanization are taking place simultaneously in the Czech Republic, with a slight dominance of the first type of tendencies. At the same time, we can keep in mind other concepts of migration "from city to countryside", and thus consider "amenity migration" (Bartoš et al. 2011), "de-urbanization", "gentrification of countryside" (Phillips 2005 in Šimon, 2011, p. 233), exurban development (Taylor, 2009 in Šimon, 2011, p. 233) or peri-urban development (Fisher, 2003; Ford, 1999 in Šimon, 2011, p. 233). Such concepts consider a quality evaluation of particular migration processes.

Semantic differences between counterurbanization and suburbanization could be defined from a spatial point of view: the term "suburbanization" denotes a deconcentration of the population within the frame of a metropolitan region (city-hinterland), whereas counterurbanization describes interregional deconcentration (Šimon, 2006). However, the exact demarcation of the spatial frontier between suburbanization and counterurbanization is generally a purposefully-defined construction. Some authors demarcate this frontier through the evaluation of commuting (Escribano, 2007). Temelová et al. (2011) 
note, however, that mobility (job and services commuting) is a crucial factor for rural people, even in peripheral areas, and thus can not be used for the demarcation of suburban space.

In the Czech Republic, strong urbanization is featured in this period. Champion (1998) provides explanations for migration from urban to rural regions but most of these can not be applied to the situation in the Czech Republic due to its political situation and central planning. Some of them, however, are applicable, such as the concentration of people from rural areas into local centres. Changes after 1990 can be accounted for by supported migration routes, suburbanization and counterurbanization. Counterurbanization could be influenced by the following reasons: more expensive living costs and social problems in cities; government donations for rural activities; more accessible and improved transport routes and communication technologies; improvement of education, health-care and other infrastructures in rural areas; increasing numbers of jobs in public/personal services; and economic recession influencing out-migration from rural areas to urban zones (Champion, 1998). Some factors (such as changing residential preferences of people and entrepreneurs) influence the suburbanization process to a greater extent, which is why it is necessary to analyze changes in public preferences.

Some migration streams from urban to rural areas could be classified as "amenity migration". There are two types of amenity migration: (i) a migration to ancient, culturally well-preserved downtowns of cities, and (ii) migration to rural conservation areas. Our research deals with the second type of migration - from urban areas to rural communities, where migrants find a pleasant and well-protected environment. Only a specific segment of the population has this preference. Some areas that suffered depopulation both in the past and present, are well protected environmentally, and thus have the potential to draw new residents. If these new migrants come, they may bring new lifestyles, attitudes and modern technologies.

A principal migration stream from urban to rural areas became significant in the USA and some countries of Western Europe in the 1970s. It decreased slightly in the 1980s but grew again in the 1990s (Stewart, 2002). This caused increasing population in formerly depopulated areas, especially in the mountain regions. It is one of the main change factors for rural areas in the USA (Stewart, 2002). This trend has not been explored in the Czech Republic as it did not take effect very much. Only migration to urban zones (urbanization) or migration from urban centres to the hinterlands of cities (suburbanization), have been explored. Moss (2006) has mentioned amenity migration in the region of Šumava in 1993, and other authors (see below) have been dealing with this issue from a sociological point of view.

The second type of amenity migration in Europe has been researched firstly in the Alps or Northern Europe: Perlik (2006) analysed the process of amenity migration in the Alps; Flogfeldt (2006) described the relationship between second homes and amenity migration in Norway; and Müller (2006) discussed the development of tourism related to amenity migration in the Swedish mountains (Tärna). The following researchers have addressed amenity migration in the Czech Republic: Librová (1994, 2003), Bartoš, Kušová (2005) and Bartoš et al. (2005). Librová (1994, 2003) discussed a specific group of amenity migrants, from a sociological point of view. She researched the reasons why people change their life habits and move from large cities to rural peripheral areas in order to live in a rural traditional way, in mostly uncultivated homesteads or farms. "Neo-ruralists", who are most inclined to a selfconscious defence of a rural way of life, are described by Gerlach, Lošták and Mooney (2008) in the context of the "new social movements" paradigm in Eastern Europe, even evident in the communist era.

Bartoš et al. (2005) have analysed how tourism supports amenity migration. Rural migration can also be enhanced by the dynamic development of communication and information technologies (Reinöhlová, 2005). Rural space can become an option for locating businesses that are based on those technologies. In addition, the prices of the land in rural areas can be influential.

Some authors work with the optimistic hypothesis that amenity migration slows down the depopulation of rural space (e.g. Chipeniuk, 2004; Glorioso, 2000). Due to this fact the inequalities of various regions are reduced and environmental and cultural quality is enhanced. However, it must be questioned whether amenity migration to rural and periphery areas is just a phase of life (see Champion, 1998), and if there are variable tendencies found in different countries.

Second homes (using cottages for a certain part of the year), which is widespread in the Czech Republic, is considered fundamental to amenity migration. Moreover, this type of habitation is well mapped and there are various Czech scientists dealing with this topic, such as Bičík et al. (2001), Vágner, Fialová et al. (2004), or Bartoš et al. (2005).

The following analysis will deal only with permanent migration, because statistics about in-migration and out-migration are processed. Next, we need to assume 
that amenity migrants will be just a small part of the total number of migrants. Regardless, as a first step in the amenity migration analysis we will deal with migration and migration streams generally.

There is an interesting Czech survey related to the possible development of amenity migration, called "Our society" (Naše společnost). It was published by the Public Opinion Research Centre of the Sociological Institute in May, 2003. A sample of 1,048 people 15 years of age and older were interviewed. Though this survey was focused on how people are willing to move because of a new job, one of the most frequent reasons to move was not work, but rather dissatisfaction with living conditions in the place of residence (Lux et al., 2006). Based on this statement we consider the amenity migration research very important in order to discover internal migration trends in the Czech Republic, with special attention to migration trends to the rural areas of the Czech Republic.

\section{Methodological approach}

To study migration in the rural areas of the Czech Republic, it is necessary to define a rural area. The term "rural area" is mostly associated with villages, landscapes covered by agricultural land, forests, water bodies, and towns that are centres of local socioeconomic development. It is also possible to use the term countryside.

Defining rural areas is not a simple issue and different countries use different criteria. It is obvious, however, that the terms "rural area" and "town" mingle, because features of urban life style penetrate into the furthest rural settlements (Müller, 2005). Generally, most of the socio-economic criteria cannot be used for more than one country at face value. The most common criterion is population density. OECD developed a definition in order to compare conditions in different areas. This definition distinguishes two hierarchical levels - local and regional. Rural areas on a local level are identified as areas with a density lower than 150 inhabitants per $\mathrm{km}^{2}$. For our purposes, we analysed our case study using current administrative units, and the surface area of municipalities as of $1^{\text {st }}$ January, 2010. A map of the distribution of rural areas in the Czech Republic is made according to this criterion. Rural areas defined on a local level cover 81.9 per cent of the territory of the Czech Republic and contain 29.5 per cent of the population.

OECD defines three types of region on a regional level "predominantly" rural areas (more than 50 per cent of the population live in villages), "substantially" rural areas (15-50 per cent of the population live in villages), "predominantly" urban areas (less than 15 per cent live in villages). Those settlements where density is below 100 inhabitants per $\mathrm{km}^{2}$ are defined as "villages".

From the regional point of view, "predominantly rural areas" occupy 22.6 per cent of the Czech Republic, with 8.5 per cent of the Czech population. "Substantially rural areas" occupy 62.8 per cent of the Czech Republic with 47.4 per cent of the population. "Predominantly urban areas" occupy 14.7 per cent of the Czech Republic with 44.1 per cent of the population. If there are less than 2,000 permanent inhabitants, the municipality is then called a "village" (OECD). Based on this criterion, villages occupy 72.8 per cent of the Czech Republic area, and contain 26.4 per cent of the Czech population.

We used these three OECD classifications ("local" rural areas, "regional" rural areas, and villages with a population less than 2,000 inhabitants) to evaluate migration. For this purpose we used statistical information about in-migration and out-migration during the period 1991-2010. Data about movements from 1991 to 2004 were taken from reports about change of address and migration (reporting units were Residence Registration Offices and Regional Foreign Police Offices). Since 2005 the Czech Statistical Office has taken over the data from the Ministry of the Interior and Headquarters of the Foreign Police Office. In order to characterize migrants demographically, the following variables are used: age, family status and citizenship. Migration itself is determined by the date of moving, and previous and current place of residence. The reasons for moving are very important, to find out whether the migration is or is not an amenity migration. However, this category has not been gathered since 2005 .

To evaluate migration trends we used the databases of immigrants and emigrants of the Czech Statistical Office in the period 1991-2010. We calculated the balance for municipalities for two periods (1991-2000 and 2001-2010). We then made categories of municipalities according to the balances that we had calculated. We created five categories, and of them two categories had a negative balance (significantly negative balance - more than 20\% population decrease; negative balance - population decrease between $1 \%$ and 20\%). The next category is characterized with a very small migration balance (between minus $1 \%$ to plus $1 \%$ of the population). Two categories are characterized with a positive balance (significantly positive with more than $20 \%$ population increase; positive - increase between $1 \%$ and $20 \%$ of population). The analysis of changes in migration trends was tested following Burt et al. (2009). Statistical analysis was carried out using chi-square tests of independence in contingency tables. 
We chose three case study areas to provide detailed information and to analyse directions of migration to rural areas since 2000. These three case study areas are: Šumava (A), Třeboňsko (B) and "West Inner Periphery" (C). We chose to study these regions because we expected that their local environments would be very attractive for amenity migrants. We analyse the complete migration patterns with a special focus on villages with a population below 2,000 inhabitants, in order to distinguish urban centres. Using Geographical Information Systems, we processed maps that showed where people came from before moving, as well as where people from our regions of interest migrate to. Based on this spatial analysis we analyzed synthesis charts about immigrants and emigrants. Most of them belong to the category of economic migrants or their family members, who endeavour to improve their socio-economic position and standard of living. More often, the motive is more complex, and we considered the multifactorial determination of the migration process (Drbohlav, 2001). We still assume that the majority of migrants to rural areas are motivated by non-economic reasons (Lux et al., 2006). We propose that amenity migrants primarily move to areas with a high quality environment. For this reason, we decided to study in detail very environmentally precious areas - Šumava, Třeboňsko and the area between Křrivoklátsko and Manětínsko subregions. We propose that amenity migrants come from cities most often. That is why we categorized municipalities as follows: municipalities in the studied region, cities with more than 50,000 inhabitants, and other municipalities in the Czech Republic or abroad. We expect that foreigners (e.g. Danish or Dutch people) also move into areas with high environmental quality located in our case study regions. Similarly, we evaluated data about people who left the regions. This analysis should describe directions and level of migration into rural areas. Then the research is oriented to amenity migration (in-depth interviews with important stakeholders in the particular region, as well as interviews with the amenity migrants themselves).

\section{Characteristics of the case study regions}

\subsection{Case study of Region A: Šumava and its foothills}

The Šumava mountains, including its foothills, was until the middle of the 1990s, an example of what can be called "the marginal area" (Těsitel, 1999) - low "economic performance", depopulation tendencies, state-limited investment into economic development, with a decrease of agricultural production intensity. Such areas are typical examples of the historical outlying periphery of the Czech Republic. However, due to its natural beauty and geographical location, tourism developed in the 1990s and has become the most important economic activity in this region. Another factor influencing the development of the area is the Sumava National Park (since 1991) and Protected Landscape Area (since 1963). They were both included in the UNESCO Biospheric reservations network under the umbrella of the international programme: Man and Biosphere. On one hand, both the National Park and the Protected Landscape Areas are considered high-quality environment guarantees and thus attractive for people. On the other hand, it creates some limits related to various economic activities, such as building construction for permanent residents out of existing municipalities (Kušová et al., 2008). This area is attractive for foreign amenity migrants due to the relative cultural and economic centres in the foothills of the Šumava Mountains and the possibility to exploit services in neighbouring Bavaria or Upper Austria (Glorioso, 1999). We carried out the majority of our interviews with amenity migrants just within the region of Šumava (Bartoš at al., 2008; Bartoš, Kušová, Těšitel, 2009). It turned out that out of the three case study regions, it is the Šumava Mountains which amenity migrants preferred the most as their final migration target.

The Šumava Mountains region is perhaps the most significant area in the Czech Republic according to the land use category measuring ecological quality (Perlín and Bičík, 2007). Ecologically important areas (forests, meadows, pastures and water bodies) exceed 10-20 times other areas, which are influenced by human activities (arable land, built-up and other areas). Mountain relief is typical for this territory, which is relatively more rugged when foothills turn to mountains in the central part of the Šumava Mountains. There are also other features of the landscape character: a valley phenomenon, plateaus, forests of unique size, and lower density.

We analyzed migration for the whole territory, which administratively belongs under the following municipalities: Sušice, Vimperk, Prachatice, Český Krumlov and Kaplice. There are 141 municipalities in this territory, but only 12 of them have more than 2.000 inhabitants. Besides municipalities with extended powers (with population 7,000-13,000 people), there are seven towns with populations between 2,0004,200 inhabitants. The average size of a village with a population below 2,000 inhabitants is 496 people.

\subsection{Case study of Region B: the Treboňsko area and Česká Kanada}

This case study region is situated in the south of the Czech Republic, in the Jindřichův Hradec district, crossing the historical border with Moravia. Thus the region can be divided into two separate parts - the 
Třeboňská basin and the Česká Kanada highlands. The Iron Curtain influenced development here as it did not allow basic economic development. On the other hand it helped to preserve nature. This region has features of an "outward periphery" of the Czech Republic. The Třeboňsko region was added to the list of the UNESCO biospheric reservations in 1977 because of its huge natural resources potential. It was acclaimed a Protected Landscape Area in 1979. The water bodies in the Třeboňsko region are active places for nesting and bird migration. The original meanders of the rivers together with regularly flooded alluvial soil and woodland meadows were maintained. There are also extremely dry places of wool sands. Well-balanced natural segments of landscape and the unique and well-preserved architecture in towns and villages complement each other. From the "land use" point of view, the Třeboňsko region is a typical example of a pond landscape with a mosaic of water bodies, forests, meadows and grass lands.

The central part of the Česká Kanada area was proclaimed as a Natural Park in 2004. In comparison with the Třeboňsko area, this area is characterized by a more severe climate, vast forests and meadows, grasslands and ponds. Such a landscape character can bring to mind a comparison with lake areas in Canada.

Both areas have similar factors of attraction, which draw visitors and potential amenity migrants. These areas facilitate leisure-time activities such as hiking, cycling, water sports, picking mushrooms, fishing or hunting. Local inhabitants, however, do not consider tourism a major factor for economic development of the area. From an historical point of view, the local population has a stable character and they view newcomers suspiciously. Perhaps this is why it is possible amenity migrants are not as interested in moving to this area as much as they are to the Šumava Mountains area.

We analysed migration processes in the whole area, which administratively belongs to the municipalities with extended powers of Jindřichův Hradec and Třeboň. There are 83 municipalities in total and eight of them have more than 2,000 inhabitants. Besides municipalities with extended powers (with 22,000 inhabitants, respectively 8,800 inhabitants), there are six municipalities with a population between 2,000 and 3,700. The average size of the rest of municipalities (with populations below 2,000) is 331 inhabitants.

\subsection{Case study of Region C: "West Inner Periphery"}

This area is a typical example of the inner periphery of the Czech Republic. It borders three Czech regions the Plzeňský, the Středočeský and the Ústecký regions. Typical features of this area are: low economic performance, long-term depopulation, a former orientation to agriculture and poor infrastructure. In the past, this area was less exposed, remote from main urban centres and from main transport arteries. A very important decrease of population took place right after the Second World War, when German-speaking people were displaced, especially from the western part of this area. It is a typical agriculture - forest landscape. On the east it borders the Krrivoklátsko Protected Landscape (since 1978) and the Biospheric Reservation of Křivoklátsko (1977), whose core area is currently being considered for national park status. The Rakovnicko area - peripheral to the Středočeský region - has good potential due to the natural, cultural and historical heritage, and it can be used for tourism development or amenity migration inducement. There are various attractive areas around the rivers Střela (Fig. 1 - see cover p. 4), Javornice, Berounka, and the entire Křivoklátsko. On the east of the Křivoklátsko, suburbanization influenced by the capital Praha (Prague) can be observed.

The territory of case region $\mathrm{C}$ is divided into a few landscape units. Forested hill country in the western part of the territory represents a region, whose structure was harmed right after World War Two. Manětínsko has a varied agricultural landscape with more rugged terrain and dominant morphological features, such as neo-volcanic forested table mountains. The settlement structure is characterized by small and architectonically precious localities. The middle part of Kralovicko is characterized by a higher proportion of arable land. The landscape quality is lower, but transport accessibility to Plzen is very good. The territory then continues to Křivoklátsko, where forests prevail (in particular places even the original forest occurs) and it makes this area ecologically stable (Kopp, Novotná, 2008). The landscape characteristics are influenced very much by the deep canyons of the Berounka and Strela rivers and their tributaries. Forested valleys that are almost untouched create a foundation for the ecological landscape network. There are dominating rock outcrops on the steep elevations of valleys, sometimes highlighted by historical remains of medieval castles (Křivoklát, Rabštejn) or castle ruins (Krašov). Some sections of the valleys became targets for second houses: in particular for people from Praha, Plzeň (Pilsen) and the Most area.

We analysed almost the entire territory under the authority of Kralovice and Rakovník (municipalities with extended power), but excluded the territory under the influence of Plzen and Praha because of the good transport system. For the same reason we excluded areas administrated by Nové Strašecí and Plasy municipalities. The area 
comprises 96 municipalities. Only two municipalities have more than 2,000 inhabitants and they have extended power (16,000 and 3,500 inhabitants). The average population of municipalities with population under 2,000 people is 379 inhabitants.

\section{Results}

\subsection{Migration in rural areas}

The population changes of municipalities in the Czech Republic between 1991 and 2010 demonstrate an increase of the number of inhabitants, especially in suburbanized areas around cities (Fig. 2).
Based on an analysis of the population size of municipalities, it is clear that the population increased after 2000 in 71 per cent of municipalities defined as rural at the local level, and in 57 per cent of rural municipalities at the regional level (see Table 1). Compared to the 1990s, the number of rural municipalities with increasing population was 37 per cent (local level) higher or 26 per cent higher (regional level). We can see that the "counterurbanization" process, which took place in both the USA and Western Europe, has started in the Czech Republic too. The change of the population size in rural municipalities measured on a regional level shows that villages in semi-rural regions are the

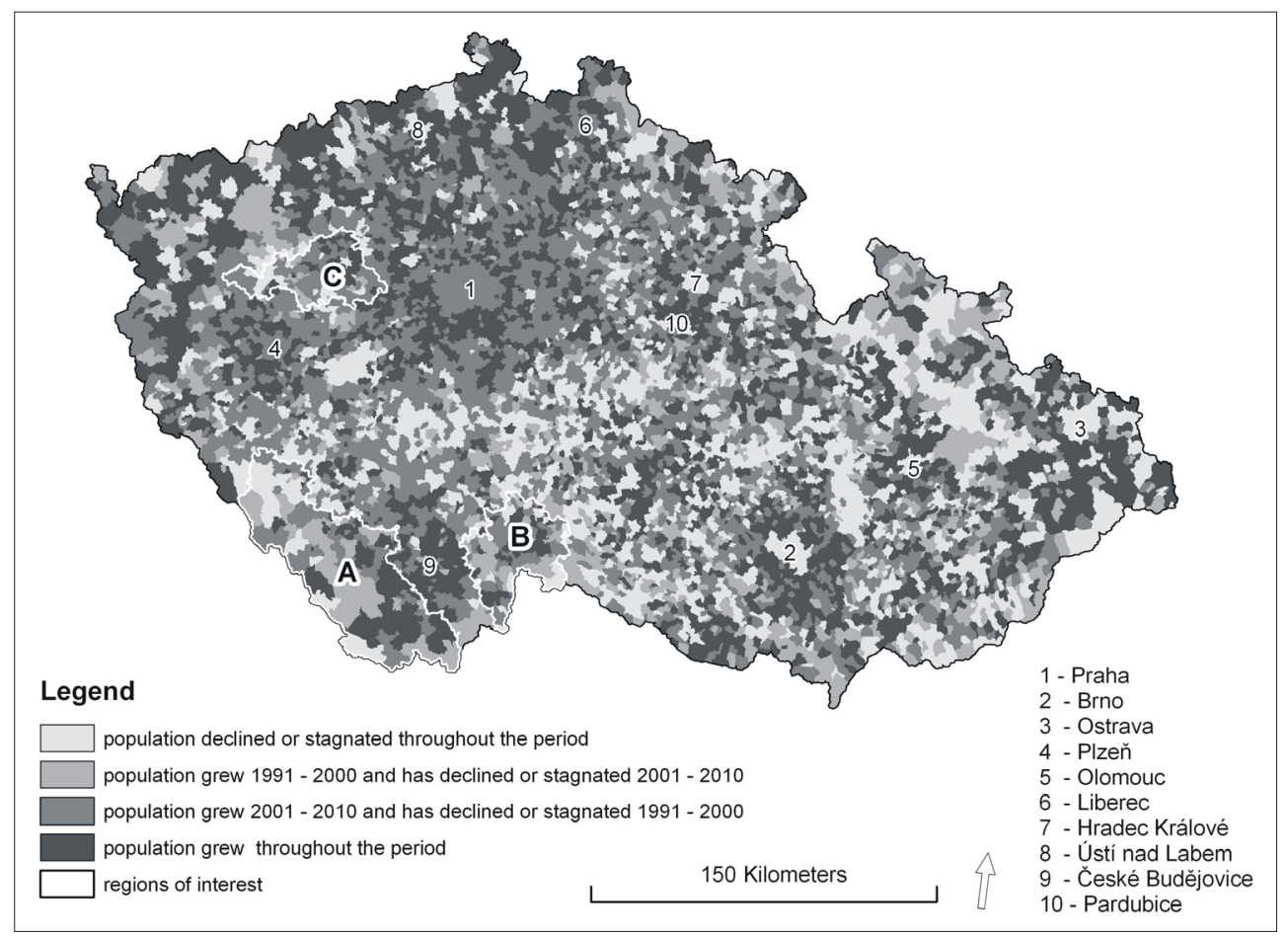

Fig. 2: Population changes in the municipalities of the Czech Republic in 1991-2010 (A - Šumava and its foothills region; $B$ - Třeboňsko area and Česká Kanada; $C$ - West Inner Periphery region)

Source: Czech Statistical Office (ČSÚ, 2011), Authors' elaboration

\begin{tabular}{|l|c|c|c|c|c|c|}
\hline \multicolumn{2}{|c|}{ Type of region } & $\mathbf{3}$ & $\mathbf{2}$ & $\mathbf{3}$ & $\mathbf{4}$ \\
\cline { 3 - 7 } & & \multicolumn{3}{c|}{$\%$} \\
\hline \multirow{3}{*}{ Local level } & urban & 18.3 & 13.7 & 20.5 & 47.6 \\
\cline { 2 - 7 } & rural & $\mathbf{1 6 . 4}$ & $\mathbf{1 2 . 4}$ & $\mathbf{3 8 . 9}$ & $\mathbf{3 2 . 3}$ \\
\hline \multirow{3}{*}{ Regional level } & urban & 6.8 & 8.0 & 27.1 & 58.1 \\
\cline { 2 - 7 } & semirural & 16.8 & 11.9 & 39.0 & 32.4 \\
\cline { 2 - 7 } & rural & $\mathbf{2 3 . 6}$ & $\mathbf{1 9 . 1}$ & $\mathbf{3 3 . 8}$ & $\mathbf{2 3 . 4}$ \\
\hline Municipalities with more than 2000 inhabitants & & 26.0 & 19.9 & 19.0 & 35.1 \\
\hline Municipalities less than 2000 inhabitants & $\mathbf{1 5 . 5}$ & $\mathbf{1 1 . 7}$ & $\mathbf{3 8 . 6}$ & $\mathbf{3 4 . 2}$ \\
\hline All municipalities & 16.6 & 12.6 & 36.5 & 34.3 \\
\hline
\end{tabular}

Tab. 1: Classification of municipalities by type of region: development of population size, 1991-2010

1 - number of inhabitants was decreasing in whole period 1991-2010; 2 - number of inhabitants increased in period 1991-2000, in period 2001-010 decreased or stagnated; 3 - number of inhabitants decreased or stagnated in the period 1991-2000 and increased in period 2001-2010; 4 - number of inhabitants increased in whole period 1991-2010 Source: Czech Statistical Office, 2011, Authors' elaboration 
fastest growing. The growth of urban regions is still obvious and we can still observe strong suburbanization processes. The results of size differentiation among the municipalities could be explained likewise. As for the age structure of rural municipalities, an older population predominates (ČSÚ, 2010). Population development thus influences the natural rate that has been decreasing. In spite of the fact that the population in rural areas naturally decreases, migration into those regions can be considered significant.

Figure 3 shows the regional differentiation in the balance of migration in the period 1991-2000, and Fig. 4 depicts regional differentiation in the following period (2001-2010).

In the period 2001-2010, the ratio of municipalities belonging to the category "rural area" on a local level, and also with a positive migration balance, was 25.0 per cent higher than in 1991-2000. In contrast, the ratio of municipalities with significantly negative balance decreased. On a regional level we can see a similar trend: there was a 20.1 per cent increase in the category of municipalities in rural areas with a positive migration balance, comparing the period 2001-2010 with 1991-2000. Again, a significant decrease of municipalities with a significant negative migration balance was recorded (see Table 2). Chisquare tests of independence in the seven contingency tables revealed very significant changes of migration trends between the periods 1991-2000 and 2001-2010 for all categories of municipalities, but somewhat less for those municipalities with more than 2,000 inhabitants or urban areas on a local level.

After 2000, the migration turnover grows. More people move and rural areas are significantly involved in this process. The data in Table 3 show that an in-migration ratio into rural areas in 2001-2010 was minor in comparison with the period 1991-2000, but this figure is influenced by the fact that foreign in-migration to urban areas significantly increased after 2000 .

In the previous analysis no migration directions are measured and observed. It is not just currently measurable in adequate ways to distinguish if people move in the frame of particular region types, or among individual types. These directions could be partly described by analysis of "inter-district migration" (Fig. 5). However, this regional division is not appropriate for research in rural areas. Hence, we researched migration in detail in the case study areas, which had been divided into certain categories.

\subsection{Migration in the case study regions}

The absolute number of immigrants and emigrants has been growing in all case study regions since 2000 . The Chi-square tests $(\mathrm{df}=6)$ revealed that there are no significant differences between the relative structure of migration to or from the three case regions in the period 2000-2007 (see Tabs. 4 and 5). In all three case regions, the population increased in those

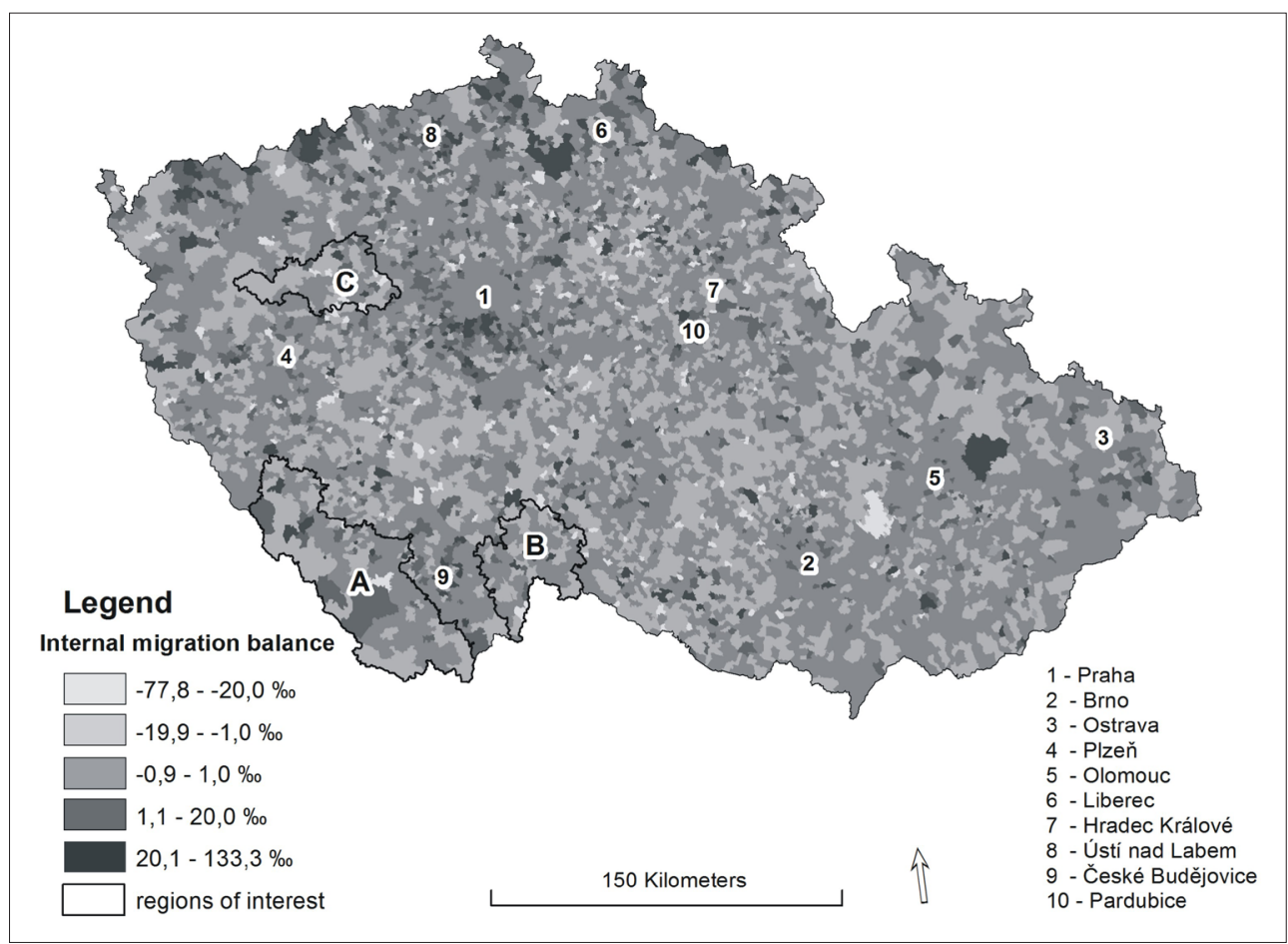

Fig. 3: Internal migration balance in the municipalities of the Czech Republic, 1991-2000

Source: Czech Statistical Office (ČSÚ, 2011), Authors' elaboration 


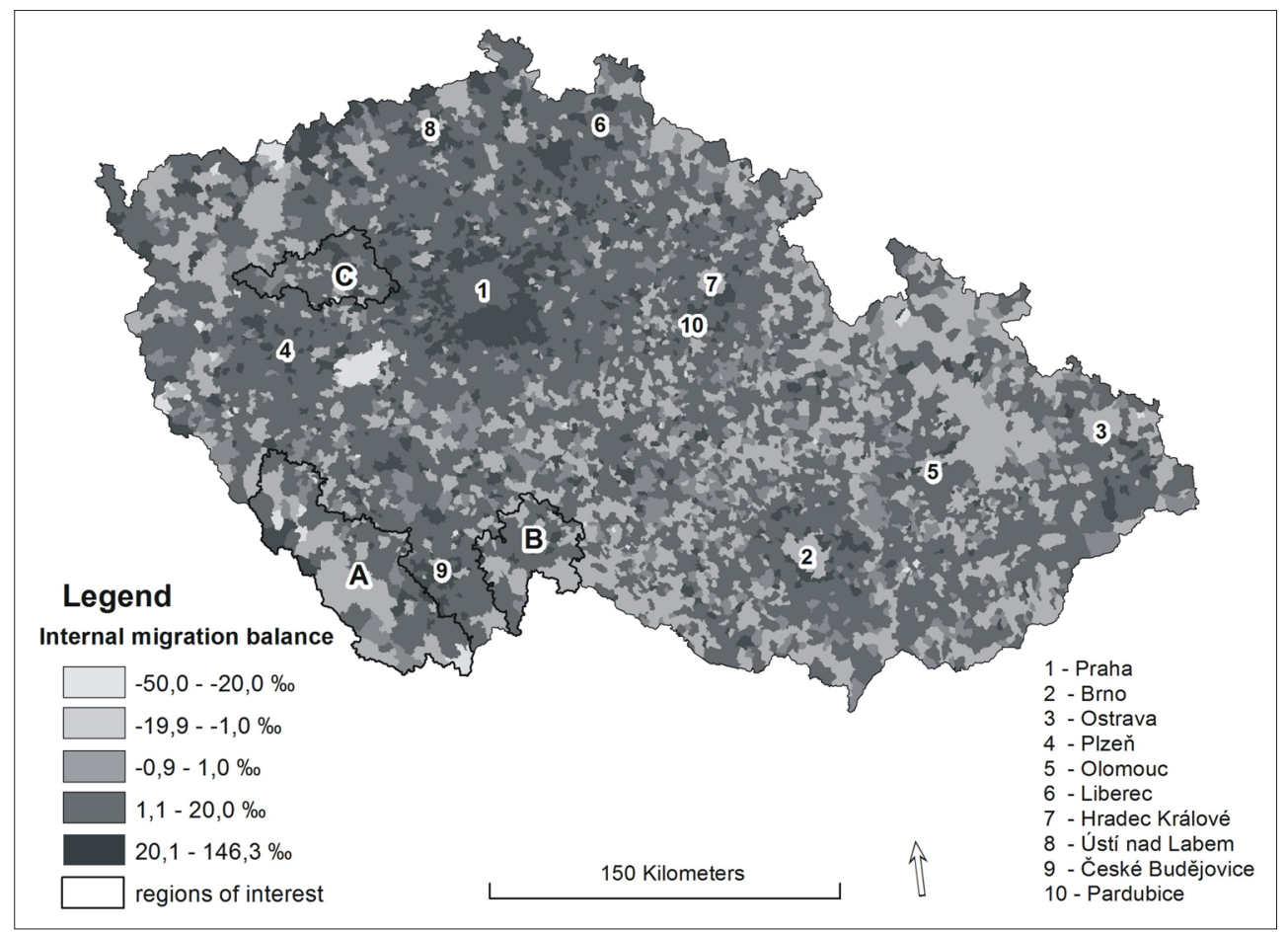

Fig. 4: Internal migration balance in the municipalities of the Czech Republic, 2001-2010 Source: Czech Statistical Office (ČSÚ, 2011), Authors' elaboration

\begin{tabular}{|c|c|c|c|c|c|c|c|c|}
\hline \multicolumn{2}{|r|}{ Type of region } & 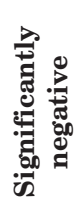 & 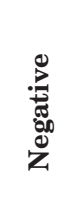 & 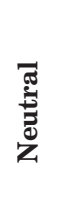 & $\sum_{\substack{0.0 \\
0}}^{0}$ & 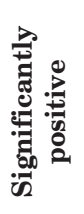 & $\begin{array}{l}\text { तేँ } \\
\text { हैं }\end{array}$ & 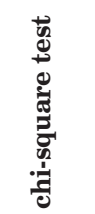 \\
\hline \multirow{4}{*}{ Local level } & urban area 1991-2000 & 1 & 194 & 123 & 484 & 39 & 841 & \\
\hline & urban area 2001-2010 & 1 & 191 & 86 & 407 & 156 & 841 & 83.43 \\
\hline & rural area $1991-2000$ & 177 & 2,087 & 623 & 2,321 & 197 & 5,405 & \\
\hline & rural area 2001-2010 & 34 & 1,057 & 442 & 3,218 & 654 & 5,405 & 855.79 \\
\hline \multirow{6}{*}{ Regional level } & urban area 1991-2000 & 9 & 172 & 78 & 537 & 56 & 852 & \\
\hline & urban area 2001-2010 & 2 & 78 & 39 & 500 & 233 & 852 & 162.52 \\
\hline & semirural area 1991-2000 & 129 & 1,629 & 534 & 1,880 & 146 & 4,318 & \\
\hline & semirural area 2001-2010 & 18 & 862 & 373 & 2,564 & 501 & 4,318 & 648.62 \\
\hline & rural area 1991-2000 & 40 & 480 & 134 & 388 & 34 & 1,076 & \\
\hline & rural area 2001-2010 & 15 & 308 & 116 & 561 & 76 & 1,076 & 97.78 \\
\hline \multicolumn{2}{|c|}{ Municipalities with more than 2000 inhabitans $1991-2000$} & & 170 & 135 & 346 & 18 & 669 & \\
\hline \multicolumn{2}{|c|}{ Municipalities with more than 2000 inhabitans 2001-2010 } & & 221 & 86 & 316 & 46 & 669 & 31.13 \\
\hline \multicolumn{2}{|c|}{ Municipalities with less than 2000 inhabitans 1991-2000 } & 178 & 2,111 & 611 & 2,459 & 218 & 5,577 & \\
\hline \multicolumn{2}{|c|}{ Municipalities with less than 2000 inhabitans 2001-2010 } & 35 & 1,027 & 442 & 3,309 & 764 & 5,577 & 926.43 \\
\hline
\end{tabular}

Tab. 2: Typological characteristics of municipalities in the Czech Republic by migration balance

Source: Czech Statistical Office, 2011, Authors' elaboration 


\begin{tabular}{|c|c|c|c|c|c|c|c|c|c|c|c|}
\hline \multirow{3}{*}{\multicolumn{2}{|c|}{$\begin{array}{l}\text { Type of region } \\
\text { classification }\end{array}$}} & \multirow{4}{*}{ 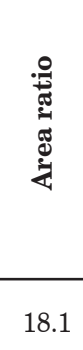 } & \multirow{4}{*}{ 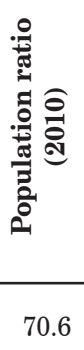 } & \multicolumn{4}{|c|}{$\begin{array}{l}\text { In-migrants } \\
\text { (average figure per } 1 \text { year) }\end{array}$} & \multicolumn{4}{|c|}{$\begin{array}{l}\text { Out-migrants } \\
\text { (average figure per } 1 \text { year) }\end{array}$} \\
\hline & & & & \multicolumn{2}{|c|}{$1991-2000$} & \multicolumn{2}{|c|}{$2001-2010$} & \multicolumn{2}{|c|}{$1991-2000$} & \multicolumn{2}{|c|}{$2001-2010$} \\
\hline & & & & total & $\%$ & total & $\%$ & total & $\%$ & total & $\%$ \\
\hline \multirow{3}{*}{$\begin{array}{l}\text { Local le- } \\
\text { vel }\end{array}$} & urban & & & 123,144 & 62.8 & 181,459 & 66.3 & 120,110 & 64.1 & 168,771 & 69.8 \\
\hline & rural & 81.9 & 29.4 & 73,083 & 37.2 & 92,351 & 33.7 & 67,385 & 35.9 & 73,158 & 30.2 \\
\hline & total & 100.0 & 100.0 & 196,227 & 100.0 & 273,810 & 100.0 & 187,505 & 100.0 & 241,929 & 100.0 \\
\hline \multirow{4}{*}{$\begin{array}{l}\text { Regional } \\
\text { level }\end{array}$} & urban & 14.7 & 44.1 & 72,745 & 37.1 & 120,333 & 43.9 & 69,186 & 36.9 & 101,920 & 42.1 \\
\hline & semirural & 62.8 & 47.4 & 101,885 & 51.9 & 129,260 & 47.2 & 97,016 & 51.7 & 117,257 & 48.5 \\
\hline & rural & 22.5 & 8.5 & 21,597 & 11.0 & 24,217 & 8.8 & 21,303 & 11.4 & 22,752 & 9.4 \\
\hline & total & 100.0 & 100.0 & 196,227 & 100.0 & 273,810 & 100.0 & 187,505 & 100.0 & 241,929 & 100.0 \\
\hline \multicolumn{2}{|c|}{$\begin{array}{l}\text { Municipalities with } \\
\text { more than } 2000 \text { inhabitans }\end{array}$} & 27.2 & 73.6 & 130,008 & 66.3 & 184,462 & 67.4 & 127,451 & 68.0 & 175,948 & 72.7 \\
\hline \multicolumn{2}{|c|}{$\begin{array}{l}\text { Municipalities with } \\
\text { less than } 2000 \text { inhabitans }\end{array}$} & 72.8 & 26.4 & 66,219 & 33.7 & 89,348 & 32.6 & 60,054 & 32.0 & 65,981 & 27.3 \\
\hline \multicolumn{2}{|l|}{ Total } & 100.0 & 100.0 & 196,227 & 100.0 & 273,810 & 100.0 & 187,505 & 100.0 & 241,929 & 100.0 \\
\hline
\end{tabular}

Tab. 3: In-migrants and out-migrants by rural or urban regions classified on local and regional levels, and municipalities classified according to size in the Czech Republic

Source: Czech Statistical Office, 2011, Authors' elaboration

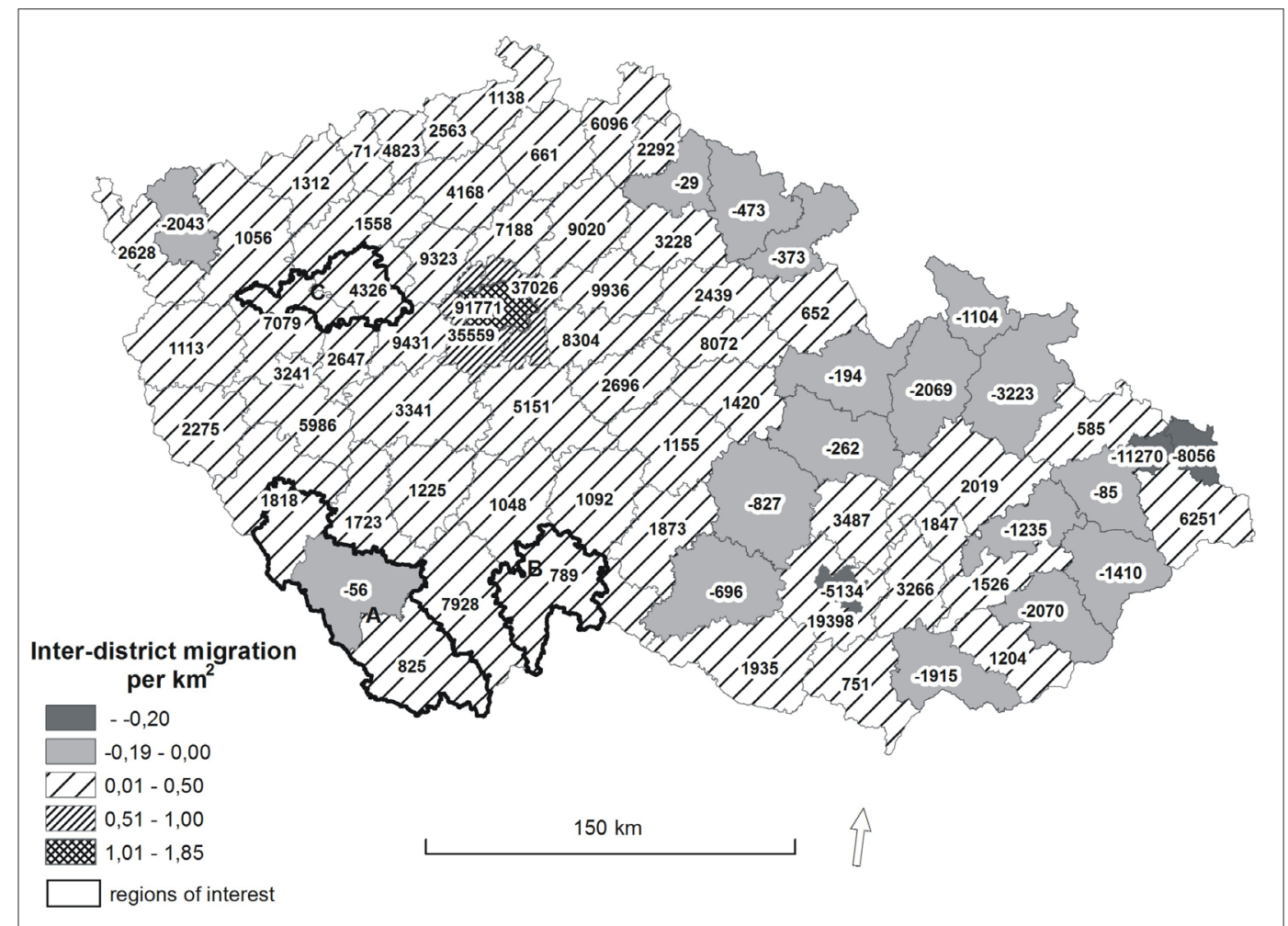

Fig. 5: Inter-district migration in the Czech Republic, 2002-2010

Source: Czech Statistical Office (ČSÚ, 2011), Authors' elaboration 


\begin{tabular}{|c|c|c|c|c|c|c|}
\hline Region & 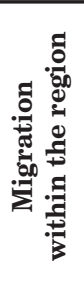 & 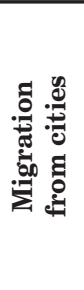 & 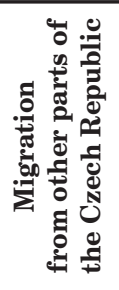 & 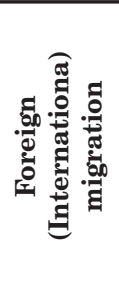 & \multirow[t]{2}{*}{ 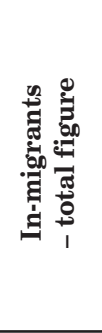 } & \multirow[t]{2}{*}{ 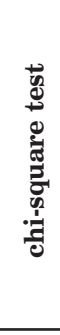 } \\
\hline & \multicolumn{4}{|c|}{$\%$} & & \\
\hline $\begin{array}{l}\text { Šumava } \\
\text { - municipalities with less than } 2000 \text { inhabitans }\end{array}$ & 48.8 & 11.9 & 24.9 & 14.4 & 17,107 & \\
\hline $\begin{array}{l}\text { Třeboňsko } \\
\text { - municipalities with less than } 2000 \text { inhabitans }\end{array}$ & 57.8 & 9.8 & 26.4 & 5.9 & 6,027 & \\
\hline $\begin{array}{l}\text { West Inner Periphery } \\
\text { - municipalities with less than } 2000 \text { inhabitans }\end{array}$ & 42.1 & 15.6 & 33.4 & 9.0 & 8,624 & 9.14 \\
\hline $\begin{array}{l}\text { Šumava } \\
\text { - municipalities with more than } 2000 \text { inhabitans }\end{array}$ & 45.0 & 12.4 & 25.2 & 17.3 & 13,125 & \\
\hline $\begin{array}{l}\text { Třeboňsko - } \\
\text { municipalities with more than } 2000 \text { inhabitans }\end{array}$ & 42.6 & 10.7 & 36.5 & 10.2 & 7,707 & \\
\hline $\begin{array}{l}\text { West Inner Periphery } \\
\text { - municipalities with more than } 2000 \text { inhabitans }\end{array}$ & 37.2 & 10.7 & 33.5 & 18.6 & 3,635 & 5.76 \\
\hline Šumava region total & 47.1 & 12.1 & 25.0 & 15.7 & 29,595 & \\
\hline Třeboňsko region total & 49.3 & 10.3 & 32.1 & 8.3 & 13,734 & \\
\hline West Inner Periphery region total & 40.6 & 14.1 & 33.4 & 11.8 & 12,259 & \\
\hline
\end{tabular}

Tab. 4: In-migration to case study regions 2000-2007

Source: Czech Statistical Office (ČSÚ, 2008), Authors' elaboration

\begin{tabular}{|c|c|c|c|c|c|c|}
\hline Region & 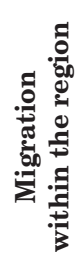 & 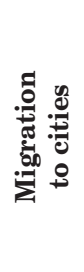 & 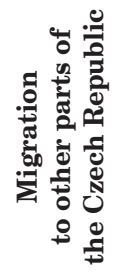 & 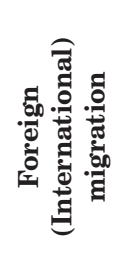 & \multirow[t]{2}{*}{ 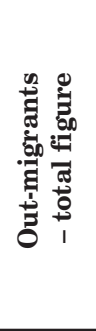 } & \multirow[t]{2}{*}{ 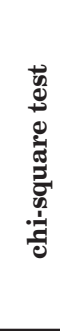 } \\
\hline & \multicolumn{4}{|c|}{$\%$} & & \\
\hline $\begin{array}{l}\text { Šumava } \\
\text { - municipalities with less than } 2000 \text { inhabitans }\end{array}$ & 53.0 & 11.2 & 28.6 & 7.2 & 14,208 & \\
\hline $\begin{array}{l}\text { Třeboňsko } \\
\text { - municipalities with less than } 2000 \text { inhabitans }\end{array}$ & 56.8 & 8.3 & 31.8 & 3.1 & 5,025 & \\
\hline $\begin{array}{l}\text { West Inner Periphery } \\
\text { - municipalities with less than } 2000 \text { inhabitans }\end{array}$ & 47.3 & 13.3 & 36.4 & 2.9 & 6,791 & 5.66 \\
\hline $\begin{array}{l}\text { Šumava } \\
\text { - municipalities with more than } 2000 \text { inhabitans }\end{array}$ & 46.0 & 15.8 & 29.7 & 8.4 & 13,932 & \\
\hline $\begin{array}{l}\text { Třeboňsko - } \\
\text { municipalities with more than } 2000 \text { inhabitans }\end{array}$ & 47.6 & 13.6 & 33.6 & 5.1 & 8,220 & \\
\hline $\begin{array}{l}\text { West Inner Periphery } \\
\text { - municipalities with more than } 2000 \text { inhabitans }\end{array}$ & 47.4 & 13.3 & 31.5 & 7.8 & 3,729 & 1.41 \\
\hline Šumava region total & 49.5 & 13.5 & 29.1 & 7.8 & 28,140 & \\
\hline Třeboňsko region total & 51.1 & 11.6 & 32.9 & 4.4 & 13,245 & \\
\hline West Inner Periphery region total & 47.4 & 13.3 & 34.7 & 4.6 & 10,520 & 2.12 \\
\hline
\end{tabular}

Tab. 5: Out-migration from case study regions 2000-2007

Source: Czech Statistical Office (ČSUU, 2008), Authors' elaboration 
municipalities with less than 2,000 inhabitants, but the municipalities with more than 2,000 inhabitants registered decreases (Fig. 6).

Between 40 and 50 per cent of migrants stay within the regions, and migration to small municipalities prevails. Migration from cities with more than 50,000 inhabitants into the regions accounts for some 10 per cent of in-migrants. This tendency is most obvious in the West Inner Periphery region. The ratio of migration from other parts of the Czech Republic to these regions is from one quarter to one third. The further away the region is located, the weaker the migration stream is (Fig. 7and 9). In-migration from outside of the Czech Republic always exceeds the reverse. Immigration from abroad is higher than migration from cities in the Šumava region.
Most of the in-migrants coming from the cities can be considered "amenity migrants", moving to the countryside for a better environment or cheaper housing, even though parcels of land in the case study regions are expensive (Bartoš et al., 2008; Bartoš, Kušová, Těšitel, 2009). The rate of migration from cities to the countryside in particular regions is as follows: in the Šumava region 12 per cent; in the Třeboňsko region 10 per cent; and, in the West Inner Periphery 14 per cent (Fig. 7). Migrants from cities move to small municipalities in particular in the Šumava (Fig. 8 - see cover p. 4) and West Inner Periphery regions, which is definitely caused by the good quality of environment there. Migration to municipalities with more than 2,000 inhabitants slightly prevails in the Třeboňsko region. Local towns such as Třeboň, Jindřichův Hradec, similar to Sušice, Prachatice and

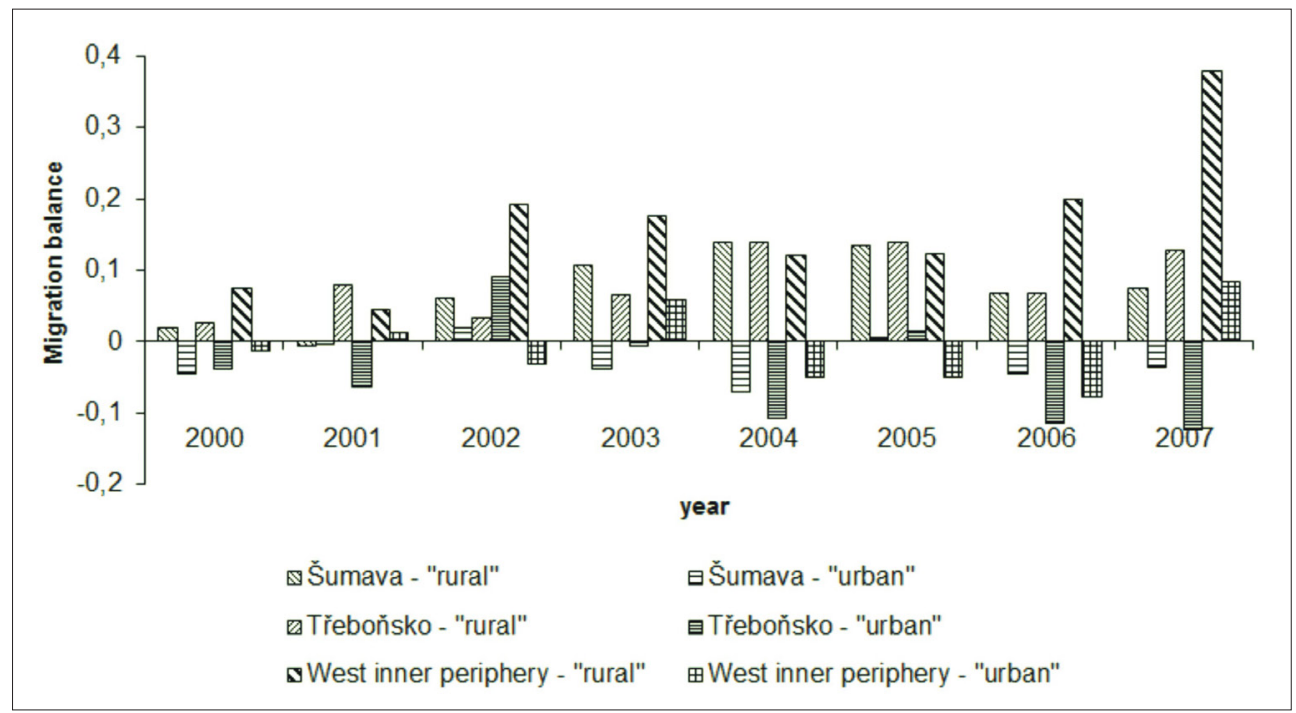

Fig. 6: Migration balance in case study regions, 2000-2007

Source: Czech Statistical Office (ČSÚ, 2008), Authors' elaboration

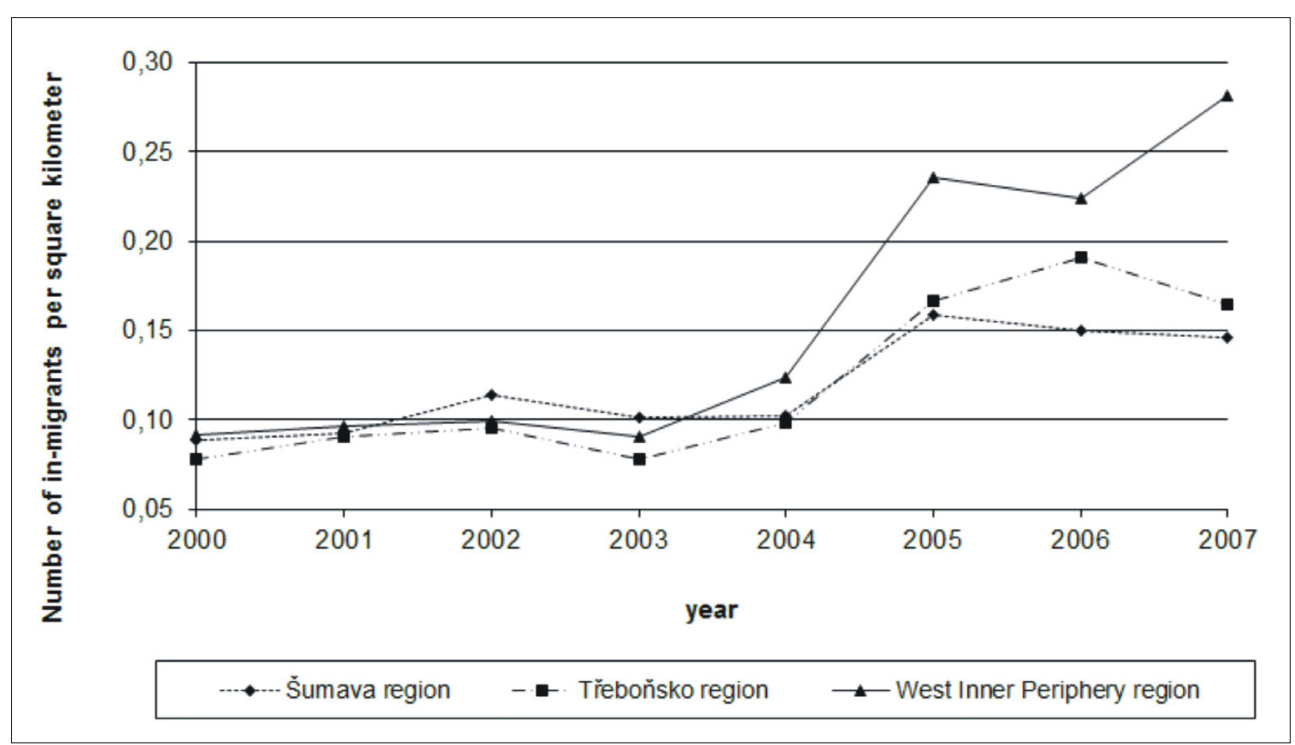

Fig. 7: Migration from cities to case study regions, 2000-2007

Source: Czech Statistical Office (ČSÚ, 2008), Authors' elaboration 
especially Český Krumlov in the Šumava region, can draw both Czech and international migrants due to their historical features. Thus "cultural amenity" migration can be defined.

Migration from foreign countries grew rapidly from 2000 to 2003, then it stagnated, but since 2006 it has grown again (Fig. 9). Most international immigrants are not amenity migrants but are labour migrants from the Ukraine, Slovakia and Vietnam, who head to these regions primarily. Amenity migrants come from Germany, the Netherlands, USA, France, Denmark or Belgium (see Table 6).

\section{Discussion}

The current state and perspectives on migration into the rural areas of the Czech Republic have to be put into the context of societal change during the era of socialism.

During the twentieth century, migration especially to towns took place in the Czech Republic. From the 1960 s to the 1980 s migration distances gradually diminished and regions and districts were closed to migration. During that time period people migrated primarily to medium-sized municipalities (between 10,000 to 50,000 inhabitants), because they

\begin{tabular}{|l|c|l|c|l|c|}
\hline \multicolumn{1}{|c|}{$\begin{array}{c}\text { Immigrants } \\
\text { to the Šmava region }\end{array}$} & Number & $\begin{array}{c}\text { Immigrants } \\
\text { to the Třeboňsko region }\end{array}$ & Number & $\begin{array}{c}\text { Immigrants to the } \\
\text { West Inner Periphery region }\end{array}$ & Number \\
\hline Germany & 176 & Austria & 43 & Germany & 23 \\
\hline Austria & 123 & Holland & 33 & France & 19 \\
\hline Holland & 83 & Germany & 18 & United Kingdom & 13 \\
\hline USA & 36 & the USA & 10 & Holland & 12 \\
\hline Italy & 15 & Italy & 8 & Denmark & 4 \\
\hline United Kingdom & 14 & Canada & 6 & Switzerland & 3 \\
\hline France & 12 & Switzerland & 2 & Australia & 3 \\
\hline Switzerland & 12 & United Kingdom & & Italy & 2 \\
\hline Canada & 9 & Belgium & & Austria & 2 \\
\hline Australia & 5 & & & & 2 \\
\hline Israel & 5 & & & & Total \\
\hline Denmark & 3 & & & $\mathbf{1 5 1}$ & 2 \\
\hline Belgium & $\mathbf{4 9 5}$ & Total & & $\mathbf{8 5}$ \\
\hline Total & & & & 2 \\
\hline
\end{tabular}

Tab. 6: International migrants from developed countries to case study regions 2000-2007

Source: Czech Statistical Office (ČSÚ, 2008), Authors' elaboration

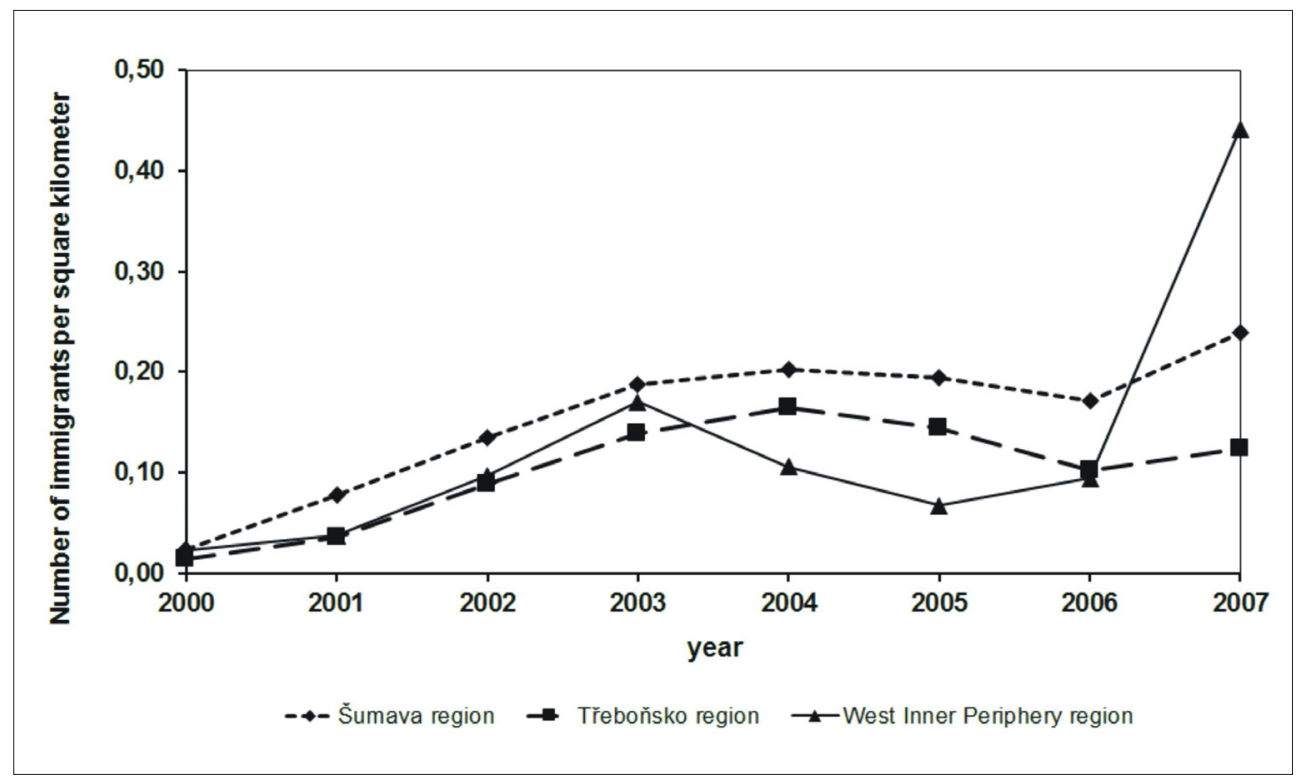

Fig. 9: Foreign immigrants to case study regions, 2000-2007

Source: Czech Statistical Office (ČSÚ, 2008), Authors' elaboration 
were the most attractive due to lots of investment and construction (Pavlík, Kučera, 2002). Essentially the municipalities became homogenized, especially the centres. Migration was weakened and particular centres became similarly important. Small municipalities and the capital Praha suffered most due to this "socialist migration policy". Praha remained naturally attractive for continuous migration, but the state used several tools to prevent this natural attractiveness, as well as sub-urbanization processes (Pavlík, Kučera, 2002).

The situation in the Czech Republic was due to the fact that people moving to urban areas still used properties in rural areas as recreational places. The second house had become (and still is) a very important phenomenon in the Czech Republic. It has developed since the 1950s and correlates with human efforts to draw nearer to nature. Secondly, the development of second houses during socialism was also connected to limited possibilities for travelling and leisure time activities (Vágner, Fialová, 2004). Hence, at the beginning of the 1990s a decrease in the importance of second houses is recorded. However, after 2000 second houses seem to acquire a new importance once again. Some owners of rural properties could be considered amenity migrants, because they stay more than a half-year in their cottages and summer houses. They are mostly pensioners who do not have many commitments or obligations.

After 1989 a decrease in internal migration is recorded. There were two reasons: first, a bad situation in the market with properties with regulated rents, problems with restitutions, and some aspects of tenure reform, as discussed by Lux, Sunega (2010); and secondly, due to the specific Czech mentality related to proprietorship. While the statistics show that 220,000 people moved during 1989, the number decreased to 160,000 in 1996. The process of spatial mobility of the population thus decreased, and the process of concentration of the population had stopped (Pavlík, Kučera, 2002).

The balance of migration in the smallest villages in 1992 was significantly negative, and the population was decreasing due to migration also in towns with more than 20,000 people. During the 1990s, towns with 5,000 inhabitants and less became the most attractive for migrants (Pavlík and Kučera, 2002). In contrast, towns with 10,000 and more inhabitants lost their residents. Decentralization thus occurred - the most attractive destinations are those towns that are situated outside of the administrative borders of larger municipalities. Praha is the most obvious example of such a trend - its population has been decreasing since 1990 (in 1999, the population balance was $-4,000$ inhabitants). Clearly, this is the suburbanization process ${ }^{1}$ (Pavlík and Kučera, 2002; Müller, 2009).

The suburbanization process was analysed by Ouředníček (2007) in the various localities of the Praha urban region in the period 1995-2003. In addition, there is a growing importance of suburbanization around the major Hungarian, Polish and Slovak cities after 1990 (Kok, 1999; Drgoňa, Turnock, 2000).

Based on a spatial analysis of statistical data, we have determined that migration to rural areas which are further from urban centres has been growing since 2000. Rural space has become a socioeconomically differentiated territory. Similarly, many of the more remote villages with low unemployment in Hungary's rural periphery also experienced net in-migration during the post-socialist transformation (Brown, Schafft, 2002).

Ruralspacein theCzechRepublicisquitedifferentiated too, as demonstrated by the new typology developed by Perlín, Kučerová and Kučera (2000), based on a components analysis of statistical indices. The Šumava region is classified in this typology as a "recreationally problematic countryside" or as an "intensive recreational area". The regions of Třeboňsko and the West Inner Periphery are considered to be both "recreationally problematic countryside" and "core countryside". We need to mention that the "core countryside" type is impacted partially by the suburbanization processes around large cities (Praha, České Budějovice). Meanwhile, the "recreationally problematic countryside" and "intensive recreational area" types represent those areas where differentiated increase of in-migration has been identified after 2000. Potentially, this increase correlates with amenity factors.

An interesting tendency of the decentralization of settlement is now appearing, specific to the Czech countryside and towns (Librová, 2007). Librová's research assumes that the most significant factor in this movement is the desire of many people to flee from the large cities and industrial agglomerations in order to live in a healthy environment. Besides that desire, there is also the zeal to change one's life style, "which may be a significant phenomenon that responds to the historically unprecedented power of impulses generated by modern cities and by the modern era in general." (Librová, 1997, p. 38 - translated from the Czech original).

\footnotetext{
${ }^{1}$ Suburbanization processes (negative balances) have taken place in Brno (1,300 people), Plzeň (600 people), Olomouc (400 people),
} Liberec and Hradec Králove (both 300 people). 
Research focused on amenity migration (in-depth interviews with important stakeholders in the particular regions, as well as interviews with the amenity migrants themselves) then the statistical analysis was carried out. The research shows that two thirds of the respondents - amenity migrants understand "amenities" as nature, landscape, a healthy environment and quiet places (environmental reasons), 10\% see "amenities" as the possibility to own a garden or their own housing, and for $6 \%$ "amenities" means the possibility to be left alone on their own with a degree of privacy (Bartoš, Kušová and Těsitel, 2009). In the context of the push-pull theory of migration (Halliday, Coombes, 1995; Brown, Schafft, 2002), it was discovered by Bartoš, Kušová and Těsitel (2009) that the main reason for moving into a new rural place of residence was a positive attitude toward nature and landscape (main pull factor), and bad environment at the former place of residence (main push factor). The important impact of environmental factors influencing migration (quality of environment; calm; natural values of the territory) has been demonstrated in the research work of Šimon (2012), who studied such factors in model areas of the remote Czech countryside.

\section{Conclusion}

The post-socialist development of internal migration in the Czech Republic is characterized by prevailing suburbanization in the hinterlands of large cities. It turns out that the migration rate to rural areas that are farther away from urban centres has been growing since 2000 . While in the past migration from rural areas to urban areas prevailed, currently the direction is the opposite: the population in rural areas with good natural and socio-cultural environments has increased because of migration. All small municipalities in the case regions have a positive migration balance, except small municipalities in the Třeboňsko region, which have a slightly negative balance with municipalities out of their region. Municipalities in the case regions with more than 2000 inhabitants have a negative balance in comparison to small municipalities within their region and with cities in the Czech Republic.

In contrast, they have a significantly positive balance with immigrants from outside of the Czech Republic. We can propose that these trends are influenced primarily by the importance of savings as well as social problems in cities, the increase in motorization and communication technologies development, the increasing migration of pensioners, who settle in properties of second housing, and changes in the residential preferences of people and entrepreneurs.
These trends can be due to the developing amenity migration into the areas with a well-preserved environment. Theoretically this phenomenon could be identified as a start of counterurbanization in the Czech Republic. With respect to the environmental motives for amenity migration discovered in some case study areas (Bartoš et al., 2008; Bartoš, Kušová and Těšitel, 2009), the phenomenon of counterurbanization according to Mitchell (2004) could be classified rather as ex-urbanization or anti-urbanization. The increase in migration can be positively fuelled by human potential, but on the other hand can cause pressures on the landscape (Moss, 1994, 2006). This process is already observed in the hinterlands of large cities (Antrop, 2004; Ouředníček, 2007). That is the rationale for continuing to research new forms of rural settlements and the identification of negative impacts that are rooted in the conflicts between the needs of society and traditional rural landscape structures.

This article has dealt with counterurbanization using two different criteria or scales of enquiry: (i) at the level of the entire territory of the Czech Republic, and (ii) at the level of the case study regions. At the national level, migration processes highlight that the growth of population in small municipalities is significantly caused by suburbanization processes. That is why different exposures of counterurbanization have been found in different regions. The source of the migration rate is due not only to the stakeholders of amenity migration. The following reasons for migration to rural areas, as Boyle, Halfacree (1998) stated, could be specified for the studied regions: the accelerated migration of pensioners supported by the strong tradition of second homes, cheaper living costs in rural areas, improved transportation and communication technologies, as well as changing preferences of productive-age people and businessmen for living places. As Šimon (2011) points out, if counterurbanization is being studied, it is necessary not only to quantify changes in population distribution, but also to explore the qualitative shift of the population distribution itself and its purpose. Currently, there are more detailed investigations taking place in particular case study areas (Bartoš et al., 2011; Simon, 2012).

\section{Acknowledgment}

This article includes results generated by the project: "Amenity migration as an emerging form of global human migration: its role in socio-economic development of rural areas in the Czech Republic", funded by the Czech Science Foundation (GACR), No. 403/07/0714-01. We would like to thank $d r$. Dominique Moran (University of Birmingham) and Frank Zauflik, MA (Centre for Leadership Effectiveness) for language revision and editing. 


\section{References:}

ANTROP, M. (2004): Landscape change and the urbanization process in Europe. Landscape and Urban Planning, Vol. 67, p. 9-26.

BARTOŠ, M, KUŠOVÁ, D. (2005): „Amenitní“ migrace jako specifická forma globální migrace obyvatel a její vliv na kvalitu života. Životné prostredie, Vol. 39, No. 6, p. 315-318.

BARTOŠ, M., KUŠOVÁ, D., TĚŠITEL, J. (2009): Motivation and life style of the Czech amenity migrants (case study). European Countryside, Vol. 1, No. 3, p. 164-179.

BARTOŠ, M., KUŠOVÁ, D., TĚŠITEL, J. (2005): Amenity migration and tourism. In: Hasman, M., Šittler, E. [eds.]: Sustainable development and Tourism. Tábor: Faculty of Agriculture, Department of Travel Trade, p. 7-21.

BARTOŠ, M., KUŠOVÁ, D., TĚŠITEL, J., KOPP, J., NOVOTNÁ, M. (2008): Amenity migration in the context of landscapeecological research. Journal of Landscape Ecology (CZ-IALE), Vol. 1, No. 2, p. 5-21.

BARTOŠ, M. et al. (2011): Amenitní migrace do venkovských oblastí České republiky. Kostelec nad Černými lesy: Lesnická práce, $196 \mathrm{p}$.

BERRY, B. (1976): The counterurbanization process: urban America since 1970. In: Berry, B. [ed.]: Urbanisation and Counterurbanisation. Beverly Hills, California, Sage, p. 17-30.

BIČÍK, I., FIALOVÁ, D., VÁGNER, J. (2001): Druhé bydlení v Česku. Praha, Univerzita Karlova v Praze, 167 pp.

BOYLE, P., HALFACREE, K. [eds.] (1998): Migration into Rural Area. Chichester, John Wiley \& Sons, $330 \mathrm{p}$.

BROWN, D. L., SCHAFFT, K. A. (2002): Population deconcentration in Hungary during the post-socialist transformation. Journal of Rural Studies, Vol. 18, p. 233-244.

BROWN, L. (1993): Rural community satisfaction and attachment in mass consumer society. Rural sociology, Vol. 58, p. 387-403.

BURT, J., BARBER, G. M., RIGBY, D. L. (2009): Elementary statistic for geographers. New York, London, The Guilford Press, $653 \mathrm{pp}$.

ČERMÁK, Z. HAMPL, M., MÜLLER, J. (2009): Současné tendence vývoje obyvatelstva metropolitních areálů v Česku: dochází k významnému obratu? Geografie, Vol. 114, No. 1., p. 37-51.

ČSÚ (2008): Databáze demografických údajů za obce ČR. Plzeň: Český statistický úrad. (zpracování na objednávku - Depon. Katedra geografie FPE ZČU v Plzni).

ČSÚ (2011): Databáze demografických údajů za obce ČR. [online]. Český statistický úrad, Praha. [cit. 20. 2.2011]. Available at: URL: < http://www.czso.cz/cz/obce_d/index.htm >.

Drbohlav, D. (2001): Evropa a proces mezinárodní migrace. Institut pro evropskou politiku Europeum, Praha [online] [cit.10.09.2010]. Available at: URL: <www.europeum.org>.

DRGOŇA, V., TURNOCK, D. (2000): Policies for rural Eastern Europe in transition: The case of Slovakia. GeoJournal, Vol. 50, p. 235-247.

FIELDING, A. (1992): Migration social mobility: South East England as an „escalator region“. Regional Studies, Vol. 26, p. 1-15.

FIELDING, T. (1998): Counterurbanization and social class. In: Boyle, P., Halfacree, K. [eds.]: Migration into Rural Areas. Chichester, John Wiley \& Sons, p. 41-60.

FLOGNFELDT, J. (2006): Second homes, work commuting and amenity migrants in Norway's mountain areas, In: Moss, L.A. G. [ed.]: The amenity migrants: Seeking and sustaining mountains and their cultures. Wallingford, UK and Cambridge, USA, CABI Publishing, p. 232-244.

GEYER, H. S., KONTULY, T. M. (1993): A Theoretical Foundation for the Concept of Differential Urbanization. International Regional Science Review, Vol. 17, p. 157-177.

GLORIOSO, S. (1999): Amenity migration in the Šumava bioregion, Czech Republic: Implications for ecological integrity. In: Gode, P. M., Price, M. F, Zimmermann. F. M. [eds.]: Tourism and development in mountain regions. Wellingford, CABI Publishing, p. 275-295.

GORLACH, K., LOŠŤÁK, M., MOONEY, P. H. (2008): Agriculture, communities, and new social movements: East European ruralities in the process of restructuring. Journal of Rural Studies, Vol. 24, p. 161-171.

HALLIDAY, J., COOMBES, M. (1995): In search of counterurbanization: some evidence from Devon on the relationship between patterns of migration and motivation. Journal of Rural Studies, Vol. 11, p. 433-446.

EGAN, A., LULOFF, A. E. (2000): The exurbanization of America's forests-research in rural social science. Journal of Forestry, Vol. 88, No. 3, p. 26-30.

ESCRIBANO, M. J. R. (2007): Migration to rural Navarre: questioning the experience of counterurbanization. Tijdschrift voor Economische en Sociale Geografie, Vol. 98, No. 1, p. 32- 41. 
HANOUSEK, J., KOČENDA, E., SVEJNAR, J. (2007): Origin and concentration: Corporate ownership, control and performance in firms after privatization. Economics of transition, Vol. 15, No. 1, p. 1-31.

CHAMPION, T. (1998): Studying counterurbanization and the rural population turnaround. In: Boyle, P., Halfacree K. [eds.]: Migration into Rural Areas. Chichester, John Wiley \& Sons, p. 21-40.

CHAMPION, T. (2001): Urbanization, Suburbanization, Counterurbanization and Reurbanization. In: Paddison, R. [ed.]: Handbook of Urban Studies. Sage Publications, London, s. 143-161.

CHIPENIUK, R. (2004): Planning for amenity migration in Canada: current capacities of interior British Columbian mountain communities. Mountain Research and Development, Vol. 24, p. 327-335.

KOK, H. (1999): Migration from the city to the countryside in Hungary and Poland. GeoJournal, Vol. 49, p. 53-62.

KONTULY, T. (1998): Contrasting the counterurbanization experience in European nations. In: Boyle P., Halfacree K. [eds.]: Migration into Rural Areas. Chichester, John Wiley \& Sons, p. 61-78.

KONTULY, T., GEYER, H. S. (2003): Lessons Learned from Testing the Differential Urbanisation Model. Tijdschrift voor Economische en Sociale Geografie, Vol. 94, No. 1, p. 124-128.

KOPP, J., NOVOTNÁ, M. (2008): Krajinně-ekologické a environmentální změny na Plzeňsku v transformačním období. In: Dubcová, A., Krogmann, A. [eds.]: Geografické informácie 12. Nitra, Univerzita Konštantína Filozofa v Nitre, p. 16-23.

KUŠOVÁ, D., TĚŠITEL, J., MATĚJKA, K., BARTOŠ, M. (2008): Biosphere reserves - An attempt to form sustainable landscapes. Landscape and Urban Planning, Vol. 84, No. 1, p. 38-51.

LIBROVÁ, H. (1994): Pestří a zelení - kapitoly o dobrovolné skromnosti. Brno: Veronica, 218 pp.

LIBROVÁ, H. (1996): Decentralizace osídlení - vize a realita. Část první: vize, postoje k venkovu a potenciální migrace v ČR. Sociologický časopis, Vol. 33, No. 1, p. 27-40.

LIBROVÁ, H. (1997): Decentralizace osídlení - vize a realita. Část druhá: decentralizace v realitě České republiky. Sociologický časopis, Vol. 32, No. 3, p. 285-296.

LIBROVÁ, H. (2003): Vlažní a váhaví. Brno, Doplněk Publishing, 320 pp.

LUX, M., SUNEGA, P. (2010): The future of housing systems after the transition - The case of the Czech Republic. Communist and Post-Communist Studies, Vol. 43, p. 221-231.

LUX, M., SUNEGA, P., MIKESZOVÁ, M., MATYÁŠ, F. (2006): Analýza opatření bytové politiky směřující k podpoře flexibility práce v ČR. 2. díl - výsledky empirických šetření. Praha: Sociologický ústav AV ČR. 132 pp.

MAJEROVÁ, V. et al. (2006): Sociologie venkova a zemědělství. Praha, Česká zemědělská univerzita v Praze. 254 pp.

MITCHELL, C. J. A. (2004): Making sense of counterurbanization. Journal of Rural Studies, Vol. 20, p. 15-34.

MOSS, L. A. G. (1994): Beyond Tourism: The Amenity Migrants, in Coherence and Chaos: Visions, Means, Action. In: Mannermaa, M., Inayatullah, S., Slaughter, R. [eds.]: School of Economics Turku, Finland, p. 125-137.

MOSS, L. A. G. [ed.] (2006): The amenity migrants: seeking and sustaining mountains and their cultures. Wallingford, UK and Cambridge, USA, CABI Publishing, 336 pp.

MÜLLER, J. (2005): Venkov očima geografa. In: Venkov, jeho proměny a územní plánování. Telč: Asociace urbanismu a územního plánování ČR, p. 4-11.

MÜLLER, J. (2009): Změny a trendy ve vývoji osídlení po roce 1990. Urbanismus a územní vývoj, Vol. 12, No. 4 Supplement, p. $11-16$.

MÜLLER, D. K. (2006): Amenity migration and tourism development in the Tärna Mountains, Sweden, In: Moss, L. A. G. [ed.]: The amenity migrants: Seeking and sustaining mountains and their cultures, Wallingford, UK and Cambridge, USA, CABI Publishing. p. 45-58.

OUŘEDNÍČEK, M. (2007): Differential Suburban Development in the Prague Urban Region. Geografiska Annaler - series B. Human Geography, Vol. 89, No. 2, p. 111-125.

OUŘEDNÍČEK, M. (2000): Teorie stádií vývoje měst a diferenciální urbanizace. Geografie, Vol. 105, No. 4, p. 361-369.

PAVLÍK, Z., KUČERA. Z. [eds.] (2002): Populační vývoj České republiky 1990-2002. Praha, Univerzita Karlova v Praze, 98 pp.

PERLÍN, R., BIČÍK. I. [eds.] (2010): Lokální rozvoj na Šumavě: závěrečná publikace shrnující výsledky projektu Analýza vývoje Národního parku Šumava za období uplynulých 15 let. Sborník z výzkumu na Šumavě, Vol. 4,Vimperk, Správa NP a CHKO Šumava, $187 \mathrm{pp}$.

PERLÍN, R., KUČEROVÁ, S., KUČERA, Z. (2010): Typologie venkovského prostoru Česka. Geografie, Vol. 115, No. 2, p. $161-187$.

REINÖHLOVÁ, E. (2005): Informační a komunikační technologie pro rozvoj periferních oblastí. In: Novotná, M. [ed.]: Problémy periferních oblastí. Praha, Univerzita Karlova v Praze, p. 36-43. 
SLEPIČKA, A. (1981): Venkov a/nebo město, lidé, sídla krajina. Praha: Svoboda, 367 pp.

STEWART, S. I. (2002): Amenity migration. In: Luft, K., MacDonald, S. [eds.]: $5^{\text {th }}$ Outdoor Recreation and Tourism Trends Symposium. Michigan State University Department of Park, Recreation and Tourism Resources, Lansing MI, p. 369-378.

ŠIMON, M. (2006): Teoretické přístupy ke studiu urbanizace. Karlova univerzita v Praze, Přírodovědecká fakulta, katedra sociální geografie a regionálního rozvoje. 43 pp. [www.urbanizace.cz - 20.06.2008].

ŠIMON, M., OUŘEDNÍČEK, M., NOVÁK, J. (2009): Search of Counterurbanization: Some Evidence from the Czech Republic. ${ }^{\text {rd }}$ International Workshop on Post-communist Urban Geographies: Actors Shaping Urban Change, 17. 9. 2009, Tartu, Estonsko, MS.

ŠIMON, M. (2011): Kontraurbanizace: Chaotický koncept? Geografie, Vol. 116, No. 3., p. 231-255.

ŠIMON M. (2012): Exploring Counterurbanization in a Post-Socialist Context: Case of the Czech Republic. Sociologia ruralis. Article first published online: 11 OCT 2012, DOI: 10.1111/j.1467-9523.2012.00576.x.

TAMMARU, T. (2003): Urban and rural population chase in Estonia: patterns of differentiated and undifferentiated urbanisation. Tijdschrift voor Economische en Sociale Geografie, Vol. 94, No. 1, p. 112-123.

TEMELOVÁ, J., NOVÁK, J., POSPÍŠILOVÁ, L., DVOŘÁKOVÁ, N. (2011): Každodenní život, denní mobilita a adaptační strategie v periferních lokalitách. Sociologický časopis, Vol. 43, No. 4, p. 831-858.

TĚŠITEL, J., KUŠOVÁ, D., BARTOŠ, M. (1999): Non marginal parameters of marginal areas. Ekológia (Bratislava), Vol. 18, No. 2, p. 39-46.

VÁGNER, J., FIALOVÁ, D. et al. (2004): Regionální diferenciace druhého bydlení v Česku. Praha, Univerzita Karlova, 286 pp.

WALMSLEY, D. J., EPPS, W. R., DUNCAN, C. J. (1998): Migration to the New South Wales North Coast 1986-1991: Lifestyle Motivated Counterurbanization. Geoforum, Vol. 29, No. 1, p. 105-118.

\section{Authors' addresses:}

Assoc. Prof. RNDr. Marie NOVOTNÁ, CSc., e-mail: novotnam@kge.zcu.cz

RNDr. Jiří PREIS, PhD. e-mail: jpreis@kge.zcu.cz

RNDr. Jan KOPP, PhD., e-mail: kopp@kge.zcu.cz

Department of Geography, Faculty of Economics, University of West Bohemia in Plzeň

Tylova 18, 30614 Plzeň, Czech Republic

Ing. Michael BARTOŠ, CSc.

Department of Social and Cultural Ecology, Faculty of Humanities, Charles University in Prague

U Křřže 8, 15800 Praha, Czech Republic

e-mail: mbartos00@zf.jcu.cz

Initial submission 6 June 2012, final acceptance 13 August 2013

Please cite this article as:

NOVOTNÁ, M., PREIS, J., KOPP, J., BARTOŠ, M. (2013): Changes in Migration to Rural Regions in the Czech Republic: Position and Perspectives. Moravian Geographical Reports, Vol. 21, No. 3, p. 37-54. DOI: 10.2478/mgr-2013-0015. 